\title{
Hospital-based phase III cardiac rehabilitation program improves low density lipoprotein, triglyceride, and fasting blood glucose levels in coronary artery disease patients
}

\author{
Dwiputra $\mathrm{B}^{1 *}$, Panjaitan $\mathrm{F}^{2}$, Hindoro $\mathrm{E}^{3}$, Fathoni $\mathrm{N}^{2}$, Santoso $\mathrm{A}^{1}$ \\ ${ }^{1}$ Faculty of Medicine, University of Indonesia/National Cardiovascular Center Harapan \\ Kita, Jakarta, ${ }^{2}$ Pupuk Kaltim Hospital, Bontang, East Kalimantan, ${ }^{3}$ Faculty of Medicine, \\ University of Pelita Harapan, Tangerang, Indonesia
}

\begin{abstract}
Cardiac rehabilitation (CR) is reported as effective program to improve coronary risk factors and increase exercise tolerance in patients with coronary artery disease (CAD) after cardiac events. Normally, the CR program is performed in 3 phases i.e. acute (phase I), subacute (phase II), and chronic (phase III). In Indonesia, the most CR programs were conducted using phase I and some phase II, whereas phase III CR program has not often been performed due to it is not covered by national health insurance. The aim of the study was to evaluate the effects of phase III comprehensive CR program on physical status and coronary risk factors among CAD patients. Seventy-four patients were stratified as the intervention group $(n=37)$ and the control group $(n=37)$. In the intervention group, patients participated in an hospital-based phase III CR program for 6 months, whereas in the control group, patients received a standard care. The $\mathrm{CR}$ program consists of warm-up, aerobic exercise, cool-down stretching, and health education session three days a week. Blood glucose level and lipid profile examinations were performed before and sixth month after the program implemented to assess patient's metabolic status. Among 74 patients involved in this study, most patients were male $(85.1 \%)$ with mean age $54.7 \pm 3.4$ years old. Fifty-seven patients had post-procedural history $(77 \%$ post$\mathrm{PCl}, 4 \%$ post-CABG), 8 patients (11\%) were still active smokers, 31 patients $(42 \%)$ had diabetes, and 60 patients $(81 \%)$ had hypertension. Participation in the hospital-based phase III CR program was significantly correlated with lower low-density lipoprotein (LDL) level $(p=0.003 ; r=0.41)$, triglyceride level $(p=0.001 ; r=0.38)$, and fasting blood glucose level $(p<0.001 ; r=0.46)$ during 6 -month follow up. In conclusion, patients with CAD who undergo hospital-based phase III CR program have significantly better fasting glucose control, LDL, and triglyceride levels. These results may encourage other hospitals to perform the same program achieving better prognosis of CAD patients.
\end{abstract}

\section{ABSTRAK}

Rehabilitasi jantung (RJ) dilaporkan merupakan program yang efektif untuk menurunkan faktor risiko dan meningkatkan toleransi latihan fisik pada pasien dengan penyakit jantung koroner (PJK) setelah kejadian kardiovaskuler. Umumnya, program RJ dilakukan dalam 3 fase yaitu fase akut (fase I), subakut (fase II) dan kronik (fase III). Di Indonesia, sebagian besar program RJ dilakukan hanya sampai fase I, beberapa sampai fase II,

Corresponding author: bambangdwiputra@gmail.com 
Dwiputra $B$ et al., Hospital-based phase III cardiac rehabilitation program improves low density lipoprotein, triglyceride, and fasting blood glucose levels in coronary artery disease patients

sedangkan program RJ fase III belum banyak dilakukan karena tidak dibiayai oleh Badan Penyelenggara Jaminan Sosial Kesehatan (BPJS Kesehatan). Tujuan penelitian ini adalah untuk mengevaluasi efek program RJ komprehensif fase III terhadap kondisi fisik dan factor risiko coroner pasien penderita PJK. Limapuluh empat penderita PJK dibagi ke dalam kelompok intervensi $(n=37)$ dan kelompok kontrol $(n=37)$. Pada kelompok intervensi, pasien menjalani program RJ fase III di rumah sakit selama 6 bulan, sedangkan kelompok kontrol pasien menjalani perawatan standar. Program RJ meliputi senam jantung sehat, senam aerobik, pendinginan dengan peregangan dan penyuluhan kesehatan 3 hari per minggu. Pemeriksaan kadar gula darah dan profil lipid dilakukan sebelum dan 6 bulan sesudah pelaksanaan program untuk menilai status metabolism pasien. Diantara 74 pasien yang terlibat dalam penelitian, sebagian besar $(85.1 \%)$ laki-laki dengan rerata umur 54,7 $\pm 3,4$ tahun. Sebanyak 57 pasien memiliki riwayat pernah menjalani operasi jantung (post-PCl 77\%; post-CABG 4\%), 8 pasien (11\%) masih aktif merokok, 31 pasien (42\%) menderita diabetes dan 60 psien (81\%) menderita hipertensi. Keikutsertaan dalam program RJ fase III di rumah sakit berhubungan nyata dengan kadar LDL $(p=0,003$; $r=0,41)$, trigliserid $(p=0,001 ; r=0,38)$ dan gula darah puasa $(p<0,001 ; r=0,46)$ yang lebih rendah setelah 6 bulan mengikuti program. Dapat disimpulkan, pasien PJK yang menjalani program RJ fase III di rumah sakit mempunyai kadar gula darah puasa, LDL dan trigliserid yang lebih baik secara nyata. Hasil ini dapat mendorong rumah sakit untu melaksanakan program yang sama dalam rangka memperbaiki prognosis pasien PJK.

Keywords: cardiac rehabilitation - high density lipoprotein - low density lipoprotein triglyceride - blood glucose

\section{INTRODUCTION}

Cardiovascular diseases (CVDs) are the leading cause of death globally. It is estimated 7.4 million deaths per year due to ischemic heart disease. ${ }^{1}$ Indonesian National Health Survey (RISKESDAS) in 2013 placed cardiac-cerebro-vascular disease as the top rank of cause of death in Indonesia. ${ }^{2}$ These catastrophic diseases are known as noncommunicable and preventable diseases. Establishing a preventive strategy, numerous studies were conducted in multicenter worldwide, in order to determine the efficacy of physical activity in reducing cardiovascular (CV) mortality. Anderson et al. ${ }^{3}$ demonstrated the importance of cardiac rehabilitation (CR) in coronary arterydisease (CAD) patients after cardiac events. This study revealed the significant benefits of $\mathrm{CR}$ to decrease total mortality, myocardial infarction, and revascularization. Moreover, CR could improve coronary risk factors, provide cost- effectiveness as secondary CVD prevention, and increase quality of life (QoL) and exercise tolerance. ${ }^{3-5}$

In general, CR programs are performed in three main stages: acute stage (phase I), subacute stage (phase II), and chronic stage (phase III).$^{6-8}$ Phase I CR starts immediately from the first day of patient admission in hospital. Phase II CR exists in a multidisciplinary program requiring a series of knowledge and skills to bring together medical treatment, risk factor control, education, exercise training, and counseling for all people with CAD. Afterward, maintaining what have been done in phase II in community is the main part of phase III CR program. ${ }^{7,8}$ In Indonesia, most cardiac rehabilitation programs have been phase I and some phase II, whereas phase III CR has not often been performed since it was not covered by National Health Insurance yet. ${ }^{9}$ Therefore, limited data are available regarding the effects of phase III cardiac 
rehabilitation on metabolic status, particularly in local population.

This study aimed to assess the beneficial effects of 6-month hospital-based phase III $\mathrm{CR}$ program on physical status and coronary risk factors among CAD patients.

\section{MATERIALS AND METHODS}

\section{Subjects}

During January-June 2016, we retrospectively enrolled 74 consecutive patients in cardiology outpatient clinic who were more than 40 years old. The all patients had been referred at least 6 months after a major coronary event, such as acute myocardial infarction, coronary artery bypass grafting, or percutaneous coronary intervention (PCI). Thirty-seven patients who consistently ( $>90 \%$ attendance) attending in a phase III CR program at Pupuk Kaltim Hospital were categorized as intervention group. Thirtyseven other patients who did not join in phase III CR program were categorized as control group. Patients with on going congestive heart failure, liver dysfunction (aspartate amino transferase $\geq 40 \mathrm{IU} / \mathrm{L}$ ), renal dysfunction (creatinine $\geq 2.0 \mathrm{mg} / \mathrm{dL}$ ), or systemic diseases (malignancy and collagen disease) were excluded.

\section{Protocols}

Entire subjects were directed for blood sample work up in order to have base line of metabolic parameters, comprise of body mass index (BMI), blood pressure, lipid profile (low-density lipoprotein/LDL, highdensity lipoprotein/HDL, total cholesterol and triglycerides), blood glucose profile (fasting and 2 hours post prandial blood glucose levels) in 0 and 6 months observation. These laboratory parameters were determined in Pupuk Kaltim Hospital laboratories using direct measurement by homogenous assay of COBAS INTEGRA 400 plus analyzer.

In the intervention group, subjects participated in a hospital-based phase III CR program, while the control group received usual outpatient care, including monthly medical examination by the physician in charge. Phase III CR program consists of warm-up (senam jantung sehat) for 10 minutes, aerobic exercise for the next 40 minutes, cool-down stretching for last 10 minutes, and health education session three days a week. Blood pressure and heart rate were monitored during the program and in outpatient clinic. Laboratory measurements were performed at the beginning and sixth month to assess patient's metabolic status.

Except for the rehabilitation protocol, standard medical care was provided for both groups. Lipid-lowering drugs (simvastatin or atorvastatin $20 \mathrm{mg}$ ) that may affect lipid levels were given at stable doses for at least 4 weeks before entry, and the doses of these medications were not altered during the study period). The Research Ethics Committee of Pupuk Kaltim Hospital approved the protocol. All subjects received full verbal and written explanations of the nature and purpose of the study, and each gave written informed consent.

\section{Data analysis}

The data analysis was conducted using SPPS version 22.0. All numeric outcomes were analyzed for Kolmogorov-Smirnov test, a test of normality. We used unpaired t-test (for normal distributed variables) or Mann-Whitney test (for abnormal distributed variables) to compare means between groups. Moreover, multivariate analysis was performed using multivariate analysis of variance test. 


\section{RESULTS}

Among 74 patients involved in this study, most patients were over 50 years old and male dominant (81\% in CR group and $89 \%$ in nonCR group, $85 \%$ of overall subjects). Mean of BMI in CR group was $26.9 \pm 3.1 \mathrm{~kg} / \mathrm{m}^{2}$, compared to $27.3 \pm 3.4 \mathrm{~kg} / \mathrm{m}^{2}$ in non-CR group. Non-CR group had slightly high percentage of hypertension, diabetes mellitus, smokers, and previous history of PCI compared to CR group (86.5 vs $75.6 \% ; 43.2$ vs $40.5 \% ; 13.5$ vs $8.1 \%$ and 81.1 vs $72.9 \%$ ). In contrast, the percentage of dyslipidemia, family history of CAD, previous coronary artery bypass graft (CABG) and non-intervention subjects in CR group were marginally greater than non-CR group ( 65 vs $62.1 \% ; 24.3$ vs $19 \% ; 5.4$ vs $2.7 \%$ and 21.7 vs $16.2 \%$ ). There was no statistically difference between lipid drug consumed by the patients. Most patients received atorvastatin $20 \mathrm{mg}$ once daily instead of simvastatin. Left ventricular ejection fraction (LVEF) by echocardiography examination showed grossly equivalent in both arms and within normal limit (TABLE 1).

TABLE 1. Baseline characteristic between groups

\begin{tabular}{lccc}
\hline Characteristic & $\begin{array}{c}\mathrm{CR} \\
(\mathrm{n}=37)\end{array}$ & $\begin{array}{c}\text { non-CR } \\
(\mathrm{n}=37)\end{array}$ & $\mathrm{p}$ \\
\hline Age (years old) & $54.4 \pm 3.6$ & $55.1 \pm 3.3$ & 0.391 \\
Male [n (\%)] & $30(81.1)$ & $33(89.1)$ & 0.327 \\
BMI (kg/m², mean $\pm \mathrm{SD})$ & $26.9 \pm 3.1$ & $27.3 \pm 3.4$ & 0.299 \\
Hypertension [n (\%)] & $28(75.6)$ & $32(86.5)$ & 0.374 \\
Dyslipidemia [n (\%)] & $24(64.9)$ & $23(62.1)$ & 0.346 \\
Diabetes Mellitus [n (\%)] & $15(40.5)$ & $16(43.2)$ & 0.814 \\
Smokers [n (\%)] & $3(8.1)$ & $5(13.5)$ & 0.714 \\
Family history of CAD [n (\%)] & $9(24.3)$ & $7(18.9)$ & 0.705 \\
Previous PCI [n (\%)] & $27(72.9)$ & $30(81.1)$ & 0.678 \\
Previous CABG [n (\%)] & $2(5.4)$ & $1(2.7)$ & 0.881 \\
Non intervention [n (\%)] & $8(21.7)$ & $6(16.2)$ & 0.749 \\
Statin therapy & & & \\
- Simvastatin 20 mg [n (\%)] & $12(32.4)$ & $11(19.7)$ & 0.876 \\
- Atorvastatin 20 mg [n (\%)] & $25(67.6)$ & $26(70.3)$ & 0.891 \\
LVEF (mean \pm SD \%) & $53.0 \pm 12.1$ & $55.1 \pm 13.7$ & 0.697 \\
\hline
\end{tabular}

CR: cardiac rehabilitation (intervention group), non-CR:non-cardiac rehabilitation (control group), CAD: Coronary artery disease, PCI: percutaneous coronary intervention, CABG: coronary artery bypass graft, LVEF: left ventricle ejection fraction. The data were presented as a mean $\pm \mathrm{SD}$ values unless stated otherwise.

After 6 months observation in $\mathrm{CR}$ and non-CR group, several metabolic parameters via laboratory examination revealed some changes in terms of fasting blood levels, 2 hours post prandial blood glucose level and lipid profile (LDL, HDL, total cholesterol and triglycerides levels) if compared 0 month of baseline data. In non-CR group, grossly the data showed worsening of metabolic status compared to baseline. In contrary, the trends on reduction of those metabolic parameters were observed in CR groups (TABLE 2). 
TABLE 2. Blood glucose and lipid profile (mean $\pm \mathrm{SD} \mathrm{mg} / \mathrm{dL}$ ) pre- and post- CR program

\begin{tabular}{|l|c|c|c|c|}
\hline \multirow{2}{*}{ Variable } & \multicolumn{2}{|c|}{$\mathrm{CR}(\mathrm{n}=37)$} & \multicolumn{2}{c|}{ non-CR $(\mathrm{n}=37)$} \\
\cline { 2 - 5 } & 0 -month & 6-month & 0-month & 6-month \\
\hline Fasting blood glucose & $106.2 \pm 17.1$ & $100.1 \pm 15.8$ & $117.0 \pm 32.7$ & $119.7 \pm 44.2$ \\
$2 \mathrm{hr}$ PP blood glucose & $154.1 \pm 36.7$ & $148.8 \pm 31.3$ & $156.4 \pm 51.3$ & $154.9 \pm 58.4$ \\
\hline Total cholesterol & $175.3 \pm 39.0$ & $170.8 \pm 44.8$ & $175.2 \pm 48.5$ & $170.4 \pm 39.9$ \\
\hline LDL-cholesterol & $113.8 \pm 28.8$ & $107.1 \pm 29.2$ & $121.8 \pm 37.1$ & $124.9 \pm 27.6$ \\
\hline HDL-cholesterol & $45.1 \pm 9.4$ & $43.7 \pm 10.5$ & $42.9 \pm 13.7$ & $41.8 \pm 12.8$ \\
\hline Triglyceride & $130.1 \pm 48.4$ & $119.6 \pm 40.7$ & $153.9 \pm 63.6$ & $163.8 \pm 77.9$ \\
\hline
\end{tabular}

CR: cardiac rehabilitation (intervention group); non-CR:non-cardiac rehabilitation (control group); 2hrPP: 2-hour post prandial; LDL: low density lipoprotein; HDL: high density lipoprotein.

Subsequently, coronary risk assessment in CR group compare to non-CR group exhibited statistically significant reduction in FBG level $(\mathrm{p}<0.001)$, LDL-C $(\mathrm{p}=0.003)$ and triglycerides $(p=0.001)$. Pearson correlation test was done indicating a moderate correlation between phase III CR program and fasting blood glucose or LDL cholesterol level $(\mathrm{r}=0.46$; 0.41). Moreover, weak positive correlation between serum triglyceride and phase III CR program were observed $(\mathrm{r}=0.38)$ (TABLE 3 ). Multivariate analysis of variance showed that there was still a significant difference between $\mathrm{CR}$ and non CR group in terms of FBG, LDL, and triglyceride level when considering jointly over these 3 different variables $(p<0.001$; $\mathrm{p}=0.001 ; \mathrm{p}=0.002$ ).

TABLE 3. Blood pressure, blood glucose level, lipid profile (mean \pm SD) during follow-up

\begin{tabular}{|l|c|c|c|}
\hline Variable & CR $(\mathrm{n}=37)$ & non-CR $(\mathrm{n}=37)$ & $\mathrm{p}$ \\
\hline Systolic BP $(\mathrm{mmHg})$ & $128.1 \pm 11.5$ & $127.3 \pm 9.6$ & 0.977 \\
Diastolic BP $(\mathrm{mmHg})$ & $83.5 \pm 6.3$ & $82.1 \pm 6.2$ & 0.536 \\
\hline Fasting blood glucose $(\mathrm{mg} / \mathrm{dL})$ & $104.2 \pm 13.9$ & $119.0 \pm 14.9$ & $<0.001 ; r=0.46$ \\
\hline 2hrPP blood glucose $(\mathrm{mg} / \mathrm{dL})$ & $150.1 \pm 32.7$ & $161.4 \pm 37.3$ & 0.619 \\
\hline Total cholesterol $(\mathrm{mg} / \mathrm{dL})$ & $173.3 \pm 35.0$ & $177.2 \pm 36.2$ & 0.681 \\
\hline LDL-cholesterol $(\mathrm{mg} / \mathrm{dL})$ & $110.4 \pm 22.8$ & $121.84 \pm 22.1$ & $0.003 ; r=0,41$ \\
\hline HDL-cholesterol $(\mathrm{mg} / \mathrm{dL})$ & $44.1 \pm 8.4$ & $42.9 \pm 9.7$ & 0.176 \\
\hline Triglyceride $(\mathrm{mg} / \mathrm{dL})$ & $124.1 \pm 40.4$ & $155.8 \pm 39.1$ & $0.001 ; r=0.38$ \\
\hline
\end{tabular}

CR: cardiac rehabilitation (intervention group); non-CR: non-cardiac rehabilitation (control group); BP: blood pressure; 2hrPP: 2-hour post prandial; LDL: low density lipoprotein; HDL: high density lipoprotein. 


\section{DISCUSSION}

This research population were observed as homogenous in intervention and nonintervention group. The results presented statistically significant reduction of fasting blood glucose $(p<0.001)$, LDL cholesterol $(p<0.003)$ and triglycerides $(p=0.001)$ in phase III CR group than non-CR group. Since, one of the main pillars of $\mathrm{CR}$ is exercise training, mainly dynamic and aerobic exercise have been related with increased of cardiorespiratory fitness. ${ }^{10,11}$ Bauer et al. ${ }^{12}$ have demonstrated exercise training improves glucose metabolism, insulin signalling, lipid profile, endothelial function, and blood pressure as well as exercise tolerance, in both diabetic and non-diabetic patients. However, in diabetic patients these parameters were remarkably improved. Hindman et al. ${ }^{13}$ reported declining of FBG and blood lipid profile in diabetic patients who participated in a CR program after the onset of MI. Similarly, our study showed improved glucose metabolism and lipid metabolism, especially LDL-C and triglycerides with continued hospital-based phase III CR after cardiac events.

The basic mechanism of physical exercise in controlling blood glucose and lipid levels are consist of improvement of insulin sensitivity, by increases the activity of AMP-dependent protein kinase (AMPK), thereby stimulating the uptake and metabolism of glucose and lipids in skeletal muscles. ${ }^{14}$ These changes can be seen starting from acute phase of exercise (1-2 hours) to the chronic phase of exercise program. Abolishment of musclin expression and increment in expression of GLUT4 were also observed in physical activity to improve insulin resistance. ${ }^{15}$

Analysis of lipid profile in our study confirmed the previous investigations. A significant decrease in total cholesterol and triglycerides was also reported by other authors. ${ }^{5}$ It was found that low-intensity and moderate exercise induces an increase in HDL and decreases triglycerides in healthy subjects. However, reduction of total cholesterol is not always detectable. ${ }^{16}$ Similarly, we did not get a significant reduction of total cholesterol. However, a significant decline of LDL-C and triglyceride were observed. Other investigation was conducted, only triglyceride were significantly decreased after 12 and 24 weeks of CR in CAD patients. ${ }^{17} \mathrm{~J}$-CARP trial in Japan, ${ }^{18}$ firmly consistent with our study, it stated not only greater enhancement lipid prolife but decrement of BMI, fat mass and Apo-AI were perceived. Magkos et al. ${ }^{19}$ reported a prolonged moderate-intensity aerobic exercise augments the clearance rate of very low density lipoprotein-triglyceride (VLDL-TG) from plasma by enhancing the efficiency of VLDL-TG removal from the circulation, without affecting VLDL-TG secretion by the liver. This augmentation of clearance rate of VLDL-TG from plasma is the main reason why triglycerides significantly reduced in 6 months patients who undergoing phase III CR program.

Phase III CR program yielded LDL-C levels enhancements with statically significant and moderate positive correlation. Mean LDL-C reduction after 6 months CR program is $6.7 \mathrm{mg} / \mathrm{dL}$. The previous study revealed a $1.7 \%$ reduction in major coronary events occurred with each $1 \%$ lowering of LDL-C in CAD patient subjects. ${ }^{20}$ Notwithstanding, based on ESC guideline of dyslipidemia ${ }^{21}$ risk stratification, our subjects are categorized as very high risk patients. The target of LDL-C in very high risk population is below $70 \mathrm{mg} /$ $\mathrm{dL},{ }^{21,22}$ which means the target of LDL-C levels in our study were not yet achieved. Yet, the average improvement of LDL-C levels in 
our population reached $5 \%$ of reduction. Thus, we realized that the phase III CR program is the key component toward LDL-C target despite of optimal lipid-lowering medications. Moreover, in this study, we observed that there were no significant differences between groups in terms of statin therapy prior to the intervention.

Stevens et al. ${ }^{23}$ established the effects of fitness were somewhat more consistent than the effects of fatness. Hence, the best way to reduce the risk of mortality, fit persons need to attain or maintain a normal body weight, and normal weight persons need to attain or maintain at least a moderate level of fitness. And, the finest approach to be fit is having moderate intensity aerobic exercise regularly, 150 minutes/weeks. ${ }^{24}$ Particularly in patients after cardiac event, continuing cardiac rehabilitation program in community levels is the leading way to be fit.

\section{CONCLUSION}

This study proves that patients with CAD who underwent hospital-based phase III CR program has significantly better fasting glucose control, LDL, and triglyceride level during 6-month follow up. Although this study is the first study that attempt to explore the role of phase III CR program in post myocardial infarction patients in Indonesia, we still need a larger number of subjects that represent multi ethnicity of general population. Therefore, we strongly recommend further multicenter team works to carry out the importance of phase III CR program in metabolic improvement, so that phase III CR program can be delivered in many centers in Indonesia and covered by national insurance program. This will lead to better prognosis of future cardiac events and quality of life among CAD patients.

\section{ACKNOWLEDGEMENTS}

We thank our colleagues from National Cardiovascular Center Harapan Kita Jakarta and Pupuk Kaltim Hospital, Bontang, East Kalimantan who provided insight, financial support, and expertise that greatly assisted the research.

\section{REFERENCES}

1. World Health Organization. WHO fact sheet: global status report on non communicable disease 2014. WHO. 2014. [cited 2016 October 14]; Available from: http://www. who.int/mediacentre/factsheets/fs317/en

2. Riset Kesehatan Dasar (RISKESDAS). Jakarta: Badan Penelitiandan Pengembangan Kesehatan, Departemen Kesehatan - Republik Indonesia, 2007.

3. Anderson L, Oldridge N, Thompson DR, Olddridge $\mathrm{N}$, Zwisler $\mathrm{AD}$, Rees $\mathrm{K}$, et al. Exercise-based cardiac rehabilitation for coronary heart disease: Cochrane systematic review and meta-analysis. J Am Coll Cardiol 2016; 67(1):1-12. https://doi.org/10.1016/j.jacc.2015.10.044

4. Lavie CJ, Arena R, Franklin BA. Cardiac rehabilitation and healthy lifeStyle interventions: rectifying program deficiencies to improve patient outcomes. J Am Coll Cardiol 2016; 67(1):13-5. https://doi.org/10.1016/j.jacc.2015.09.103

5. Taylor RS, Brown A, Ebrahim S, Jolliffe J, Noorni H, Rees K, et al. Exercise-based rehabilitation for patients with coronary heart disease: systematic review and meta-analysis of randomized controlled trials. Am J Med 2004; 116(10): 682-92. https://doi.org/10.1016/j.amjmed. 2004.01.009

6. Vanhees L, Martens M, Beloka S, Stevens A, Avram A, Gaita D. Cardiac Rehabilitation: Europe. In: Perk J, Mathes P, Gohlke H, 
Monpère $\mathrm{C}$, Hellemans $\mathrm{I}$, McGee $\mathrm{H}$, editors. Cardiovascular prevention and rehabilitation. London: Springer-Verlag, 2007: 30-3. https://doi.org/10.1007/978-1-84628-502855

7. Brown RA. Rehabilitation of patients with cardiovasculardisease: report of a WHO expert committee. WHO Tech Rep Ser 1964; 270:3-46.

8. Piotrowicz R, Wolszakiewicz J. Cardiac rehabilitation following myocardial infarction. Cardiol J 2008; 15(5): 481-7.

9. Radi B. Cardiac rehabilitation in Indonesia. Global Heart 2009; 4(supp1):s49.

10. Stavropoulos-Kalinoglou A, Metsios GS, van Zanten JJV, Nightingale P, Kitas GD, Koutedakis Y. Individualised aerobic and resistance exercise training improves cardiorespiratory fitness and reduces cardiovascular risk in patients with rheumatoid arthritis. Ann Rheum Dis 2013; 72:1819-25. ht tps://doi.org/10.1136/ annrheumdis-2012-202075

11. Dalager T, Justesen JB, Murray M, Boyle E, Sjøgaard G. Implementing intelligent physical exercise training at the workplace: health effects among office workers-a randomized controlled trial. Eur J Appl Physiol 2016; 116(7): 1433-42. https://doi.org/10.1007/s00421-016-3397-8

12. Bauer TA, Reusch JE, Levi M, Regensteiner JG. Skeletal muscle deoxygenation after the onset of moderate exercise suggests slowed microvascular blood flow kinetics in type 2 diabetes. Diabetes Care 2007; 30(11): 2880-5. https://doi.org/10.2337/dc07-0843

13. Hindman L, Falko JM, La Londe M, Snow R, Caulin-Glaser T. Clinical profile and outcomes of diabetic and nondiabetic patients in cardiac rehabilitation.AmHeartJ2005;150(5):1046-51. https://doi.org/10.1016/j.ahj.2005.04.002

14. Musi N, Fujii N, Hirshman MF, Ekberg I, Fröberg S, Ljungqvist $\mathrm{O}$, et al. AMP- activated protein kinase (AMPK) is activated in muscle of subjects with type 2 diabetes during exercise. Diabetes 2001; 50(5): 921-7. https://doi.org/10.2337/diabetes.50.5.921

15. Yu J, Zheng J, Liu XF, Feng ZL, Zhang $\mathrm{XP}$, Cao LL, et al. Exercise improved lipid metabolism and insulin sensitivity in rats fed a high-fat diet by regulating glucose transporter 4 (GLUT4) and musclin expression. Braz J Med Biol Res 2016; 49(5):e5129. http:// dx.doi.org/10.1590/1414-431X20165129 https://doi.org/10.1590/1414-431X20165129

16. Durstine JL, Grandjean PW, Davis PG, Ferguson MA, Alderson NL, Du Bose KD. Blood lipid and lipoprotein adaptations to exercise: aquantitative analysis. Sports Med 2001; 31:1033-62. https://doi.org/10.2165/00007256200131150-00002

17. Sandor B, Nagy A, Toth A, Rabai M, Mezey B, Csatho A, et al. Effects of moderate aerobic exercise training on hemorheological and laboratory parameters in ischemic heart disease patients. PLoS ONE 2014; 9:1-8. https://doi.org/10.1371/journal.pone.0110751

18. Seki E, Watanabe Y, Shimada K, Sunayama S, Onishi T, Kawakami K, et al. Effects of a phase III cardiac rehabilitation program on physical status and lipid profiles in elderly patients with coronary artery disease: Juntendo Cardiac Rehabilitation Program (J-CARP). Circulation J 2008; 72:1230-34. https://doi.org/10.1253/circj.72.1230

19. Magkos F, Wright DC, Patterson BW, Mohammed BS, Mittendorfer B. Lipid metabolism response to a single, prolonged bout of endurance exercise in healthy young men. Am J Physiol Endocrinol Metab 2006; 290:E355-E362. https://doi.org/10.1152/ajpendo.00259.2005

20. Thanassoulis G, Williams K, Ye K, Brook $\mathrm{R}$, Couture P, Lawler PR, et al. Relations of change in plasma levels of LDL-C, non- 
HDL-C and apoB with risk reduction from statin therapy: a meta-analysis of randomized trials. J Am Heart Assoc 2014 Apr 14; 3(2): e000759.

https://doi.org/10.1161/JAHA.113.000759

21. Reiner Z, Catapano AL, De Backer G, Graham I, Taskinen MR, Wiklund O, et al. The task force for the management of dyslipidaemias of the European Society of Cardiology (ESC) and the European Atherosclerosis Society (EAS). ESC/EAS Guidelines for the management of dyslipidaemias. Eur Heart J 2011; 32:1769-818. https://doi.org/10.1093/eurheartj/ehr158

22. National Cholesterol Education Program (NCEP) Expert Panel on Detection Evaluation and Treatment of High Blood Cholesterol in Adults (Adult Treatment Panel III). Third
Report of the National Cholesterol Education Program (NCEP) Expert Panel on Detection, Evaluation, and Treatment of High Blood Cholesterol in Adults (Adult Treatment Panel III): Final Report. Circulation 2002; 106(25): 3143-421.

23. Stevens J, Cai J, Evenson KR, Thomas R. Fitness and fatness as predictors of mortality fromall causes and from cardiovascular disease in men and women in the lipid research clinics study. Am J Epidemiol 2002; 156(9):832-41. https://doi.org/10.1093/aje/kwf114

24. Piepoli MF, Hoes AW, Agewall S, Albus C, Brotons C, Catapano AL, et al. European Guidelines on cardiovascular disease prevention in clinical practice. Eur Heart J 2016; 37(29):2315-81. https://doi.org/10.1093/eurheartj/ehw106 